\title{
花火ビューエリアマップの作成
}

\section{Drawing up of Fireworks Viewing Area Map}

\author{
小泉 俊 雄*，小野邦 彦** \\ Toshio KOIZUMI, Kunihiko ONO
}

\begin{abstract}
The objective of this study is to draw up fireworks viewing area map. This map shows areas where fireworks can be seen well. The technical term called fireworks viewing area map is first used in this paper. On drawing up the maps, aerial photographs are taken from a height over the spot for fireworks by a kite balloon camera system. The area from where fireworks can be seen well is the same area taken by aerial photography. The paper draws up the fireworks viewing area map of Narashino city. Accuracy of the map was checked by some students during the exhibition of fireworks. The fireworks viewing area map measures $40 \mathrm{~cm}$ by $30 \mathrm{~cm}$ and has multicolor print.

本論文は花火が綺麗に見える地域を地図に表した「花火ビューエリアマップ」を作成したものである。

花火ビューエリアマップという用語は，本論文作成にあたり著者が定めたものである。

地図の作成方法は, 気球に搭載したカメラを花火の打ち上げ場所から花火が到達し開く上空地点まで飛揚させ, 視野角 360 度にわたって空中写真を撮影する。空中写真に写っている地点は, 地上から花火が見える地点であるとして地図を作成す るものである。

本論文では千葉県習志野市の「ふるさと習志野市民花火大会」の花火ビューエリアマップを作成した。 作成した地図を花火大会当日現地に持参し，その精度を確認したところほぼ満足する結果が得られた。 完成した地図は，大きさ $40 \mathrm{~cm} \times 30 \mathrm{~cm}$ の多色刷りのものである。
\end{abstract}

\section{1.はじめに}

日本の夏の風物詩である花火大会は各地で行われ大 勢の人が楽しむ。花火を主催する側や見物する側に とっても，何処で花火が綺麗に見えるかの情報は会場 設定や交通規制，場所探しなど，多くの面で取得した い事柄であると考えられる。また，主題図作成という 研究の面からも興味ある課題である。

本論文は花火が綺麗に見える地域を地四に表した 「花火ビューエリアマップ」の作成に関する研究の報告 である。花火ビューエリアマップという用語は本論文 作成にあたり著者が定めたものである。この種の主題 図としては，富士山が何処から見えるかについての地 眓が中央地図 (株)において作成されている1)。これは

* 千葉工業大学士木工学科

$* *$ 中央地図 (株)

「写真測量とリモートセンシング」Vol. 34, No. 3, 1995
地形の標高デー夕をもとに，富士山の頂上から見える 範囲を計算機によりシミュレーションしたものであ る。花火についてのものは, 東京都の墨田区役所と台 東区役所が隅田川の花火大会に際して，花火の上がる 地点にアドバルーンを揚げて，地上に配置した職員の 情報をもとにアドバルーンの見える地点を探し, 花火 が見える地点を調査したものがある2)。しかしながら これは花火のための主題図の作成を目的としたもので はなく, 花火大会の案内図や会場設定, 見物人の誘導 の資料等にするためのものである。

本研究で用いた方法は, 気球に搭載したカメラを花 火の打ち上げ場所から花火が到達し開く上空地点まで 飛揚させ，視野角 360 度にわたって空中写真を撮影し， 空中写真に写っている地点は, 地上から花火が見える 地点であるとして地図を作成するものである。この方 法は隅田川で実施されたものに比べ，人手も少なく面 的に調査でき，また，記録が写真とともに残るため， 地図作りの作業がしやすいなど多くの利点が考えられ る。本研究ではこの方法により, 千葉県習志野市の「ふ 
るさと習志野市民花火大会」の花火ビューエリアマッ プを作成した。

\section{2．ふるさと習志野市民花火大会}

千葉県習志野市は東京から電車で30分程の東京湾岸 に位置する都市である。毎年 7 月の終わに，市の主催 による市民花火大会が行われる。花火会場は海岸の埋 め立地である。この場所は周囲には数階建ての会社の ビルや大学の建物が散在し, 倉庫や事務所, 住宅や公 園，空き地や霊園などが広がる地域である。

平成 6 年は 7 月 30 日に花火大会が開催され，市内の 遠い地域からはバスで観客がピストン輸送されるなど 多くの市民で賑わった。花火の打ち上げ総数は 4,500 発 であり， 3 号〜 4 号玉1,226発，スターマイン 33 基，仕 掛花火 1 基である。多くの花火は $100 \mathrm{~m}$ から $150 \mathrm{~m}$ 上空 に上がる。図 1 に花火大会の様子を示す。

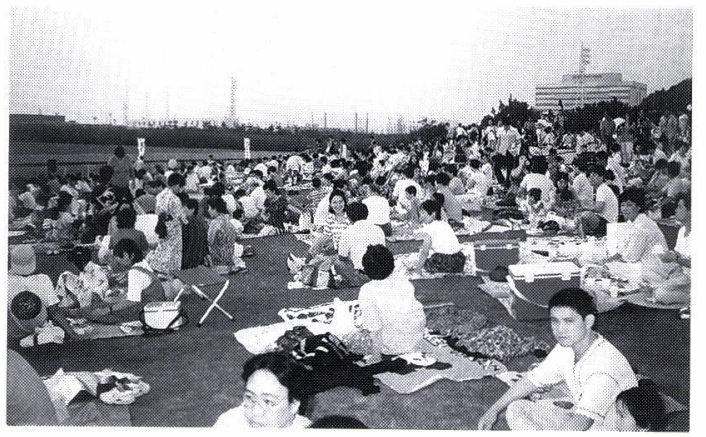

図 1 ふるさと習志野市民花火大会

\section{3. カイト気球による空中写真撮影}

著者らが開発したカイト気球による空中写真撮影装 置 ${ }^{3}$ を用いて, 花火の上がる高度 $100 \mathrm{~m}, 120 \mathrm{~m}, 150 \mathrm{~m} の$ 上空から陸地方向の斜空中写真を撮影した。図 2 に 撮影状況を示し, 図 3 に撮影された写真加ら作成した モザイク写真を示す。

\section{4. 花火ビューエリアマップの作成}

花火ビューエリアマップの作成にあたっては，先ず 主題図としての定義付けを行い, 定義に従って作成基 準を定めた。そして試作四を作成し, 花火大会当日に 現地にて精度を検証した。検証の結果有効であること
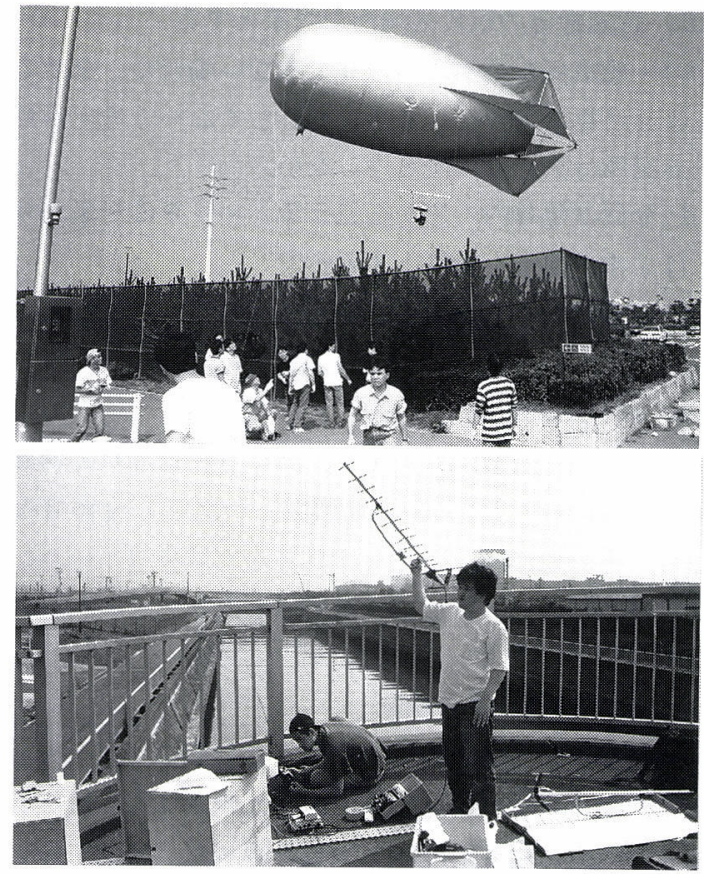

目 2 撮影状況

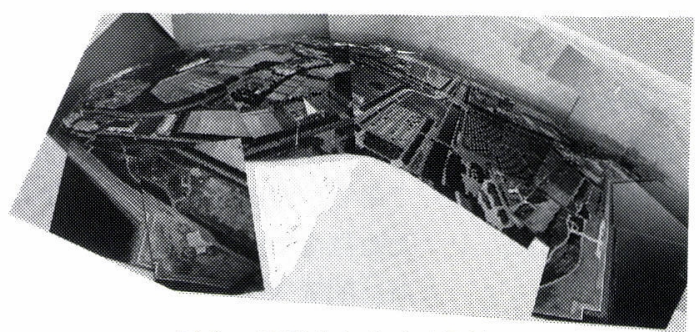

図 3 撮影された空中写真

が確かめられたので, 成果品としての地図を完成させ た。以下に各項目の詳細に付いて述べる。

(1) 定義

花火ビューエリアマップとは，花火が綺麗に見える 地域を表した地図である。

(2) 作成基準

( a ) 綺麗に見える地域とは, 花火の全体像が視認でき る場所であり，花火の打ち上げ場所からほぼ $2 \mathrm{~km}$ 以 内の地域と仮定する。

花火が見えると言っても，遠くに小さく見える地 域を見える地域と表示するのは適当でない。本来は 「綺麗に見える」という言葉の意味を科学的に求めて 定めるべきであるが，適当な方法が見いだせないの で，ここではこれまでの花火見物の経験を通して打 ち上げ場所からほぼ $2 \mathrm{~km}$ 以内と定めた。 
（b）習志野市の行政区域内を対象とする。

（c）一般市民が自由に出入りできない場所や，墓地の ように見る場所としてはふさわしくないと考えられ る場所は見える場所とはしない。

(d)今回は建物内の空から見えるという事は对象から はずす。地上を対象とする。

(e ) 高度 $100 \mathrm{~m}, 120 \mathrm{~m}, 150 \mathrm{~m}$ から写した空中写真の内 の, 全ての写真に写っている所を見える地域とする。 (3) 試作図の作成

上記の作成基準にもとずき, 撮影された写真と習志 野市作成の縮尺 $1 / 2,500$ の地形図とを照らし合わせな がら，その地形図上に花火が見える地域をフリーハン ドで書き込んだ。写真は状況に応じてサービス判から 六切り判まで拡大して使用した。

（4）試作図の精度の検証

作成した試作困の精度を検証するために, 花火大会 当日に図 4 に示寸場所に学生を 2 人から 3 人一班にし て4つの班を現地に配置し調査を行った。配置に際し ては花火が見えるべき所と, 見えないはずの所に一人 ずつ配置し，見えるべき所で花火が見えたら見えない はずの所の人に合図を行い，互いに連携を取り合う方 法で調查を行った。調查地点はある時間経ったら移動 させて, 多くの地点で検証ができるようにした。調査 地点は全部で 13 地点である。調査のデータシートに は時刻とともに，見えたか見えないかの状況を記入し た。また，見えるべき所に配置された者はできる限り 花火の写真を撮影し, 時刻も記入した。図 5 (a) は その内の 1 枚であり, 図 5 (b) はその位置で昼間に 撮影した周囲の状況の写真である。表 1 は精度の検証 地点において記入したデーターシートの一部であり, 表 2 は検証結果をまとめたものである。○は正解， は花火の一部分しか見えたり見えなかったりしたも の, ×は不正解である。表 2 より $\triangle$ を正解率 0.5 として 計算すると, 見えるべき所で見えたものは $97 \%$ あ゙り， 見えないはずの所で見えなかったものが77\%となっ た。見えないはずの所での精度が若干低かった理由は, 写真の中心投影による撮影は一点で見ている事になる が，花火は上空で広がるため両者に差が生じた為と考 えられる。この事は, 表 2 の花火が見えないはずの所 での×印の欄（花火全体が見えた所）が $0 \%$ （ 0 個） であった事からも分かる。結果として満足できる精度 と考えられる。

（5）花火ビューエリアマップ
表 1 精度検証データシート

観測者氏名 4 班 鳥山 青木 深沢 平成 6 年 7 月 30 日 (土)

\begin{tabular}{|c|c|c|c|c|c|c|c|}
\hline \multirow{2}{*}{$\begin{array}{l}\text { 場 } \\
\text { 所 }\end{array}$} & \multirow{2}{*}{$\begin{array}{l}\text { 時 } \\
\text { 間 }\end{array}$} & \multicolumn{2}{|c|}{ 見えるべき所 } & \multirow{2}{*}{ 考察 } & \multicolumn{2}{|c|}{ 見えないはずの所 } & \multirow{2}{*}{ 考察 } \\
\hline & & 見えた & 見えない & & 見えた & 見えない & \\
\hline \multirow[t]{3}{*}{4} & 19 & 0 & & \multirow{4}{*}{$\begin{array}{l}\text { 全ての } \\
\text { 花火が } \\
\text { 見える。 }\end{array}$} & & 0 & \multirow{4}{*}{$\begin{array}{l}\text { 前方に } \\
\text { 木があり } \\
\text { 見えない }\end{array}$} \\
\hline & 時 & 0 & & & & 0 & \\
\hline & 50 & 0 & & & & 0 & \\
\hline 1 & 分 & 0 & & & & 0 & \\
\hline \multirow{6}{*}{4} & \multirow{5}{*}{$\begin{array}{l}20 \\
\text { 時 } \\
20\end{array}$} & 0 & & & & $\triangle$ & \multirow{4}{*}{$\begin{array}{l}\text { 花火の } \\
\text { 高い所は } \\
\text { 見えるが } \\
\text { 低い所は }\end{array}$} \\
\hline & & 0 & & & & $\triangle$ & \\
\hline & & 0 & & & & $\triangle$ & \\
\hline & & 0 & & & & $\triangle$ & \\
\hline & & 0 & & & & $\triangle$ & \multirow{6}{*}{$\begin{array}{l}\text { 家や木が } \\
\text { じゃまで } \\
\text { 見えない }\end{array}$} \\
\hline & $\sim$ & 0 & & & & $\triangle$ & \\
\hline \multirow[t]{4}{*}{2} & \multirow{4}{*}{$\begin{array}{l}20 \\
\text { 時 } \\
27\end{array}$} & 0 & & & & $\triangle$ & \\
\hline & & 0 & & & & $\triangle$ & \\
\hline & & 0 & & & & $\triangle$ & \\
\hline & & 0 & & & & $\triangle$ & \\
\hline \multirow{4}{*}{$\begin{array}{l}4 \\
1 \\
3\end{array}$} & 20 & & $\triangle$ & \multirow{4}{*}{$\begin{array}{l}\text { 花火の } \\
\text { 下方が } \\
\text { 見えない }\end{array}$} & & 0 & \multirow{4}{*}{$\begin{array}{l}\text { 家と木が } \\
\text { 邪魔を } \\
\text { していて } \\
\text { 見えない }\end{array}$} \\
\hline & 時 & & $\triangle$ & & & 0 & \\
\hline & 30 & & $\triangle$ & & & 0 & \\
\hline & 分 & & $\triangle$ & & & 0 & \\
\hline
\end{tabular}

試作図の精度の検証において満足する結果が得られ たので,これにもとずき成果図の作成を行った。縮尺 については $1 / 2,500 の$ 地図では図示範囲が約 $90 \mathrm{~cm} \times$ $60 \mathrm{~cm}$ と大きすぎて使用に不便であるので, A3 判に収 めるために縮尺 $1 / 10,000 の$ 地図に写し直した。この $1 /$ 10,000の地図は習志野市作成のものである。また，花 火が見える場所のみを表示寸るだけでは見栄えがしな いことと，表示された内容に対して「どうしてここで は見えないのですか」という疑問がいくつか指摘され たので, 緑地, 河川, 公共施設用地, 墓地といった情 報を地困に記入し，これらの疑問を解消するよう配慮 を加えた。この結果，見やすくなるとともに，A3の大 きさに収まり扱いやすいものになった。図 6 に成果図 として作成した花火ビューエリアマップを示す。

\section{5. まとめ}

本研究では今までになかった花火ビューエリアマッ プを初めて作成した。作成手法や地図の様式等に今後 改良を加えるべき点があるが，最初に提示した点にそ の価值が見いだせると考えられる。なお，本論文で用 
表 2 精度の検証結果

\begin{tabular}{|c|c|c|c|c|c|c|c|c|}
\hline \multirow{2}{*}{ 班名 } & \multirow{2}{*}{$\begin{array}{c}\text { 花火打ち上げ地点 } \\
\text { からの直線距離 } \\
(\text { 単位 }: \mathrm{m})\end{array}$} & \multirow{2}{*}{$\begin{array}{l}\text { 花火調 } \\
\text { 査デー } \\
\text { 夕数 }\end{array}$} & \multicolumn{3}{|c|}{ 見えるべき所 } & \multicolumn{3}{|c|}{ 見之ないはずの所 } \\
\hline & & & $\bigcirc$ & $\triangle$ & $x$ & 0 & $\triangle$ & $x$ \\
\hline 1 班 & $700 \sim 1100$ & 24個 & $\begin{array}{l}100 \% \\
\text { (24個) }\end{array}$ & $\begin{array}{c}0 \% \\
(0 \text { 個) }\end{array}$ & $\begin{array}{c}0 \% \\
(0 \text { 個 })\end{array}$ & $\begin{array}{c}67 \% \\
\text { (18個) }\end{array}$ & $\begin{array}{c}23 \% \\
\text { ( } 6 \text { 個) }\end{array}$ & $\begin{array}{c}0 \% \\
(0 \text { 個) }\end{array}$ \\
\hline 2 班 & $1300 \sim 1700$ & 18個 & $\begin{array}{l}100 \% \\
\text { (18個) }\end{array}$ & $\begin{array}{c}0 \% \\
(0 \text { 個) }\end{array}$ & $\begin{array}{c}0 \% \\
(0 \text { 個 })\end{array}$ & $\begin{array}{c}61 \% \\
\text { (11個) }\end{array}$ & $\begin{array}{c}29 \% \\
\text { ( } 7 \text { 個) }\end{array}$ & $\begin{array}{c}0 \% \\
(0 \text { 個) }\end{array}$ \\
\hline 3 班 & $450 \sim 1700$ & 8 個 & $\begin{array}{c}100 \% \\
\text { ( } 8 \text { 個） }\end{array}$ & $\begin{array}{c}0 \% \\
(0 \text { 個 })\end{array}$ & $\begin{array}{c}0 \% \\
(0 \text { 個) }\end{array}$ & $\begin{array}{c}0 \% \\
(0 \text { 個 })\end{array}$ & $\begin{array}{l}100 \% \\
\text { ( } 8 \text { 個) }\end{array}$ & $\begin{array}{c}0 \% \\
(0 \text { 個) }\end{array}$ \\
\hline 4 班 & $1300 \sim 1700$ & 18個 & $\begin{array}{c}78 \% \\
\text { (14個) }\end{array}$ & $\begin{array}{c}22 \% \\
\text { ( } 4 \text { 個) }\end{array}$ & $\begin{array}{c}0 \% \\
(0 \text { 個 })\end{array}$ & $\begin{array}{c}44 \% \\
\text { ( } 8 \text { 個) }\end{array}$ & $\begin{array}{c}56 \% \\
\text { (10個) }\end{array}$ & $\begin{array}{c}0 \% \\
(0 \text { 個) }\end{array}$ \\
\hline 合計 & & 68個 & $\begin{array}{c}94 \% \\
\text { (64個) }\end{array}$ & $\begin{array}{c}6 \% \\
\text { ( } 4 \text { 個) }\end{array}$ & $\begin{array}{c}0 \% \\
(0 \text { 個） }\end{array}$ & $\begin{array}{c}54 \% \\
\text { (37個) }\end{array}$ & $\begin{array}{c}46 \% \\
\text { (31個) }\end{array}$ & $\begin{array}{c}0 \% \\
(0 \text { 個) }\end{array}$ \\
\hline
\end{tabular}

1)（）内は観測デー夕数

2）見えるべき欄の凡例

$\bigcirc$ : 花火が全く見えなかった所

$\triangle$ : 花火の一部分しか見えなかった所 $\times$ : 花火全体が見えた所
3）見えないはずの欄の凡例

$\bigcirc$ : 花火全体が見えた所

$\triangle$ : 花火の一部分しか見えなかった所

×：花火が全く見えなかった所

見えるべき所

$$
\{64+(4 / 2)\} / 68=97 \%
$$

見えないはずの所

$\{37+(31 / 2)\} / 68=77 \%$

注） $\triangle$ は 0.5 として数えた

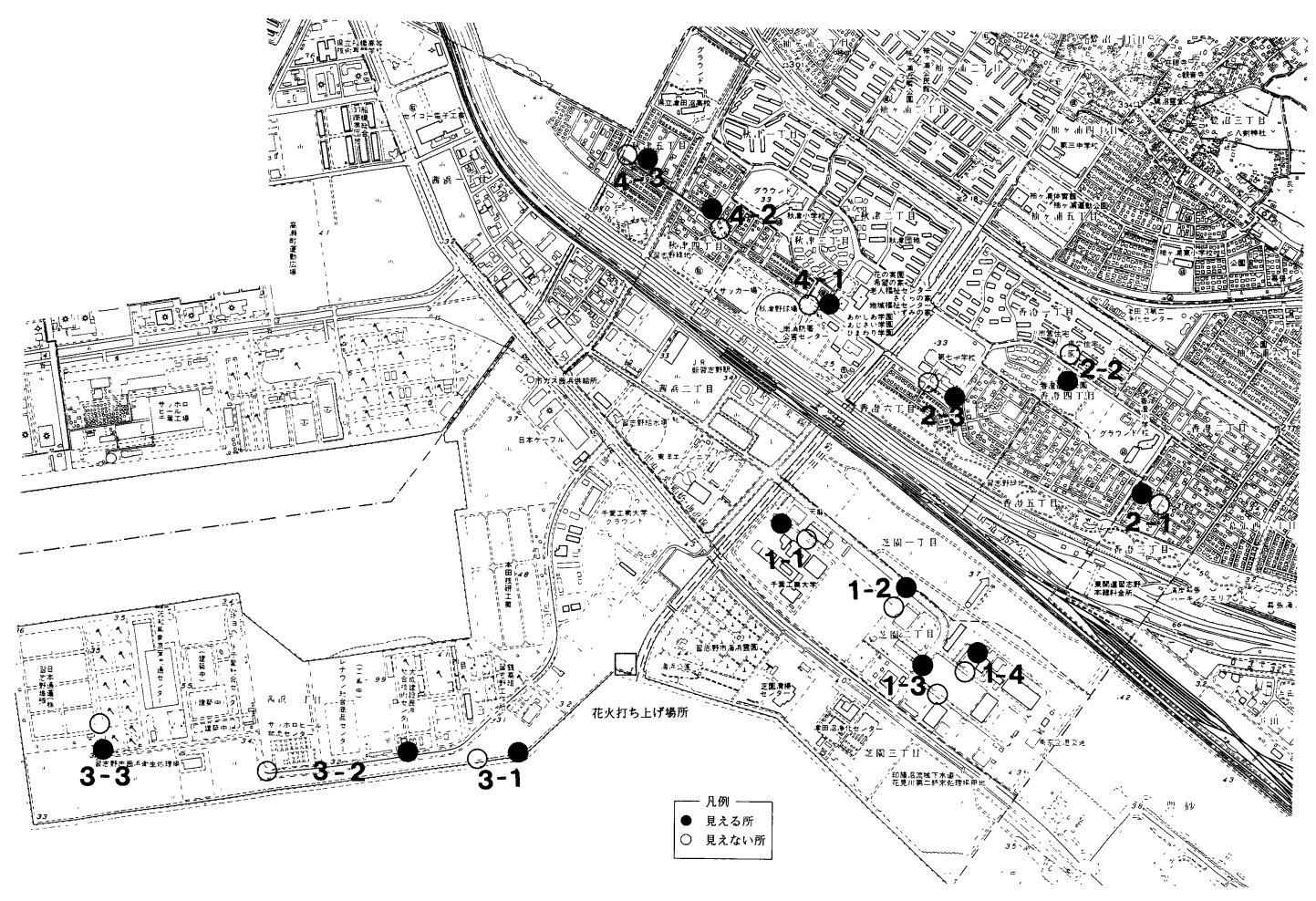

図4 精度の検証地点と花火打ち上げ場所 


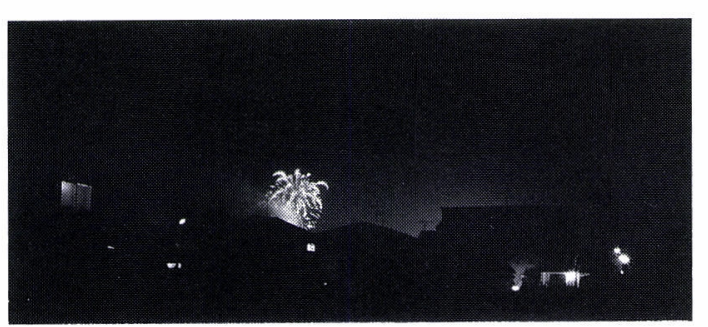

（a）精度の検証の際に撮影された写真

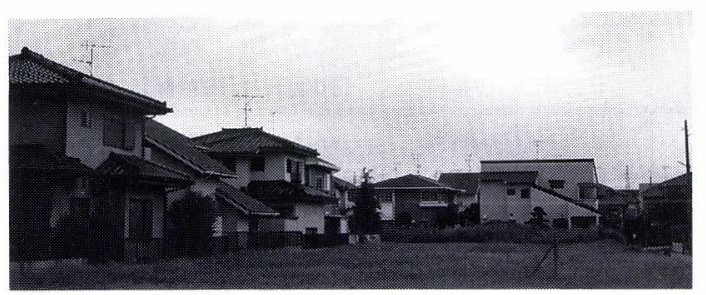

（b）（a）の写真を撮影した場所
いた作成手法は一つの方法として有効なものであるこ とが確認された。

今後は建物も含んだ 3 次元マップの作成や, 計算機 による地四作成の自動化を図りたい。また,「花火が綺 麗に見える」という抽象的表現に対して，何らかの科 学的根拠付けが必要である。

全国各地の花火ビューエリアマップを作成したいと 考之ている。（受付日1995.1.24, 受理日1995.5.12)

\section{参考文献}

1) 中央地図 (株)：富士山が見える地図

2 ）墨田区, 台東区：墨田川花火大会案内図, 平成 6 年度

3 ) 小泉, 村井, 小池, 真鍋：カイト気球を用いた空中写 真撮影システムとその応用, 写真測量とリモートセンシ ング, Vol 25,NO.3,1986 など多数

4 ）山口裕一：地図を使った風景スケッチ入門，山と渓谷 社, 1993

図 5 精度の検証地点より撮影された花火と周囲の状況 (観測地点 $4-3$ ) 


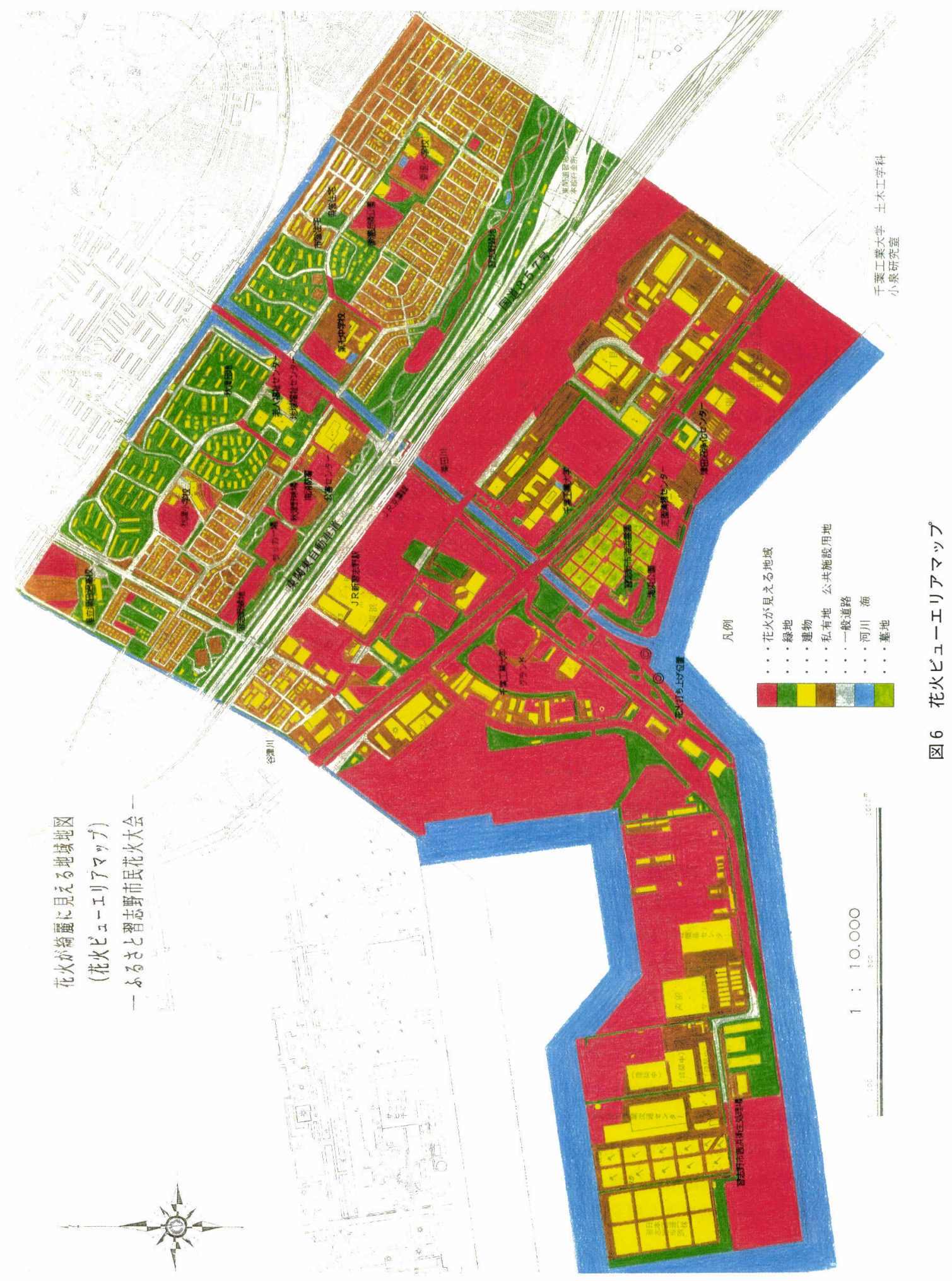

